(Fakul tas Kesehatan Universi tas Muhammadiyah Gresik)

\title{
Sosialisasi Dampak Penyalahgunaan Narkoba Di Lingkungan Masyarakat, Desa Modong, Kabupaten Sidoarjo
}

\author{
Zufra Inayah*1, Fifit Eka Furi A ${ }^{2}$, Sestiono Mindiharto ${ }^{3}$ \\ ${ }^{1,2,3}$ Program Studi Kesehatan Masyarakat; Fakultas Kesehatan; Universitas Muhammadiyah Gresik ; Jln. \\ Proklamasi Gresik \\ e-mail correspondence*: zufra.@umg.ac.id
}

\begin{abstract}
Abstrak
Prevalensi angka kematian yang disebabkan penyalahgunaan narkotika mencapai 12.044 orang per tahun dan menempatkan Indonesia dalam posisi darurat. Informasi yang kurang tentang jenis dan dampak narkoba mempunyai andil dalam peningkatan prevalensi penyalahgunaan narkoba. Peran serta masyarakat berupa sosialisasi dampak penyalahgunan narkoba di lingkungan masyarakat merupakan salah satu upaya penanggulangan yang komprehensif. Metode penelitian pra-eksperimental dan jenis penelitian lapangan dengan pendekatan cross sectional. Kelompok sasaran adalah warga desa modong sebanyak 26 orang yang merupakan perwakilan dari aparatur desa, perangkat desa, rukun warga dan rukun tetangga serta karang taruna. Bentuk kegiatan adalah penyuluhan. Kajian analisa menggunakan wilcoxon test. Hasil kegiatan pengmas, peserta sebagian besar karang taruna sebanyak $38 \%$, pengetahuan peserta sebelum penyuluhan kurang sebanyak $83 \%$ dan setelah penyuluhan pengetahuan peserta meningkat baik sebanyak $67 \%$. Analisa statistik signifikan, nilai $\mathrm{p}$ value $=0,00$ yang menunjukan perbedaaan meningkat. Pengmas sosialisasi dampak penyalahgunaan narkoba di lingkungan masyarakat desa diperlukan sebagai upaya penanggulangan penyalahgunaan narkoba untuk menekan peningkatan prevalensi kasus narkoba khususnya desa modong dan kabupaten sidoarjo.
\end{abstract}

Kata kunci-Sosialisasi, Dampak, Penyalahgunaan, Narkoba,

\begin{abstract}
The prevalence of death rates caused by narcotics abuse reaches 12,044 people per year and puts Indonesia in a position of emergency. Lack of information about the types and impacts of drugs has contributed to the increasing prevalence of drug abuse. Community participation in the form of socialization of the impact of drug abuse in the community is one of the comprehensive countermeasures. Pre-experimental research methods and types of field research with a cross sectional approach. The target group is 26 people in Modong village who are representatives of the village apparatus, village officials, neighborhood and neighborhood groups as well as youth organizations. The form of activity is counseling. Analysis studies using the Wilcoxon test. The results of community service activities, most of the participants were youth organizations as much as 38\%, $83 \%$ less knowledge of participants before intervention and after intervention the participants' knowledge improved by $67 \%$. The statistical analysis is significant, the $p$ value $=0.00$ which shows the difference increases. Socialization of the impact of drug abuse in the village community is needed as an effort to combat drug abuse to reduce the increase in the prevalence of drug cases, especially in Modong Village and Sidoarjo Regency.
\end{abstract}

Keywords - socialization, impact, abause, drugs. 


\section{PENDAHULUAN}

Narkoba atau narkotika merupakan obat yang dapat menenangkan syaraf, menghilangkan rasa sakit,menimbulkan rasa ngantuk atau merangsang. ${ }^{[1]}$ narkotika juga didefinisikan sebagai obat zat yang dapat menenangkan syaraf, mengakibatkan ketidaksadaran atau pembiusan, menghilangkan rasa nyeri dan sakit, menimbulkan rasa ngantuk dan merangsang, menimbulkan efek stupor serta dapat menimbulkan adiksi atau kecanduan dan yang ditetapkan oleh Menteri kesehatan sebagai narkotika. ${ }^{[2]}$ Penyalahgunaan narkoba adalah penggunaan narkoba secara berkala atau teratur diluar indikasi medis, sehingga menimbulkan gangguan kesehatan fisik, psikis dan gangguan fungsi $\operatorname{sosial.~}^{[2,3]}$

Bahaya narkoba menempatkan Indonesia dalam posisi darurat, karena angka kematian yang disebabkan penyalahgunaaan narkotika mencapai 12.044 orang meninggal per tahun atau 33 orang per hari. angka kematian didapatkan dari konsumsi narkoba dalam dosis berlebih, mengkonsumsi lebih dari satu jenis narkoba secara bersamaan dan mengkonsumsi narkoba setelah absen lama. ${ }^{[2]}$

Prevalensi penyalahgunaan narkoba tahun 2014 sebesar 4 juta jiwa pada usia 10-59 tahun. Penggunaan narkotika meliputi 1,6 juta orang mencoba, 1,4 juta orang pemakai secara teratur dan 943 ribu orang pecandu. Berdasarkan asal wilayah pemakai narkoba di pulau jawa menempati posisi tertinggi sebanyak 2,416,5 ribu jiwa diikuti sumatra sebanyak 849,5 ribu jiwa, kalimantan 238,3 ribu jiwa, sulawesi 267,6 jiwa, bali dan nusa tenggara sebanyak 169,6 ribu jiwa, maluku 42,1 ribu jiwa dan papua sebanyak 38,9 ribu jiwa. Jumlah kerugian akibat penyalahgunaan narkotika sekitar Rp. 63,1 triliyun terdiri dari kerugian pribadi sebesar Rp. 56,1 triliyun dan kerugian sosial Rp. 6,9 triliyun. ${ }^{[4]}$

Jenis narkoba yang disita sebagai barang bukti tahun 2014 antara lain sabu kristal 377.416, 42 gram, ekstasi 14.914 butir, Heroin 7.894,68 gram, ganja daun 8.156.827,69 gram, ganja pohon 60 batang, ganja biji 102 gram, cairan toluene 5.810 ml, cairan HCL $700 \mathrm{ml}$ dan Epidrine bubuk 1,9 gram, Aseseton cair $5.980 \mathrm{ml}$ dan cairan lainnya $6.763 \mathrm{ml}^{\left[{ }^{[4]}\right.}$

Data kasus narkotika di Kabupaten Sidoarjo Tahun 2015 jumlah perkara sebanyak 219 dan tersangka 268, tersangka terdiri dari pengedar 186 orang dan pemakai 82 orang. Tahun 2016 jumlah perkara sebanyak 431 dan tersangka 493 yang merupakan pengedar. ${ }^{[4]}$

Ketidaksiapan secara mental serta ketidaktahuan akan dinamika media sosial serta tekanan rekanan yang buruk menggiring mereka pada penyalahgunaan narkotika. ${ }^{[5]}$ Data kasus narkotika yang meningkat memerlukan upaya penanggulangan secara komprehensif dengan melibatkan kerjasama multidisipliner, multisektoral dan peran serta masyarakat secara aktif, konsekuen, konsisten dan berkesinambungan. Desa modong yang merupakan mitra Prodi Kesehatan Masyarakat adalah salah satu desa di kabupaten Sidoarjo, diharapkan sosialisasi dampak penyalahgunaan narkoba di lingkungan masyarakat tersebut dapat menekan prevalensi kasus narkoba.

\section{METODE}

Pengabdian masyarakat ini dilakukan dengan penyuluhan sebagai bentuk kegiatan sosialisasi dampak penyalahgunaan narkoba di lingkungan masyarakat. Metode penelitian yang digunakan 
adalah pra-eksperimental dengan jenis penelitian lapangan dan pendekatan waktu secara crossectional.

\subsection{Khalayak Sasaran}

Peserta penyuluhan adalah remaja, kepala keluarga / orang tua dan tokoh masyarakat. Jumlah sasaran penyuluhan sebanyak 26 orang dengan mempertimbankan efisiensi dan efektifitas program serta jumlah anggaran program.

\section{2 Lokasi dan Waktu kegiatan}

Lokasi kegiatan di desa Modong kabupaten Sidoarjo, tempat di balai desa modong kecamatan tulangan kabupaten sidoarjo. Waktu kegiatan pada hari sabtu tanggal 27 Juli 2019 pukul 06.00 WIB sampai selesai, sedangkan kegiatan penyuluhannya di lakukan pada pukul 19.00 s/d 21.00WIB. Kegiatan penyuluhan dilakukan pada waktu malam hari agar tidak menggangu jadwal kerja yang ada.

\subsection{Metode}

Kegiatan penyuluhan yang dilakukan menggunakan metode ceramah dan diskusi. Tahapan dalam penyuluhan meliputi kegiatan pre-tes dan pos t-tes untuk pengidentifikasi tentang pengetahuan jenis dan dampak penyalahgunaan narkoba pada peserta penyuluhan. Kajian analisis yang digunakan adalah wilcoxon test. Outcome pada kegiatan ini adalah meningkatkan kesadaran masyarakat terhadap penyalahgunaan narkoba.

\section{HASIL DAN PEMBAHASAN}

Peserta kegiatan penyuluhan sosialisasi dampak penyalahgunaan narkoba di lingkungan masyarakat, desa modong, kabupaten sidoarjo meliputi Aparat Pemeritah Desa (APD), Lembaga Pemberdayaan Masyarakat Desa (LPMD), Bintara Pembina Desa (Babinsa), Badan Permusyawaratan Desa (BPD), Rukun Tetangga (RT) atau Rukun

Warga (RW) dan Karang Taruna (Kartar). Distribusi peserta penyuluhan terdapat pada tabel 1 .

Tabel 1. Distribusi Peserta Penyuluhan

\begin{tabular}{lcc}
\hline Peserta & Jumlah & Prosentase \\
\hline APD & 2 & $8 \%$ \\
LPMD & 1 & $4 \%$ \\
Babinsa & 1 & $4 \%$ \\
BPD & 4 & $15 \%$ \\
Kartar & 10 & $38 \%$ \\
RT / RW & 8 & $31 \%$ \\
\hline Total & 26 & $100 \%$ \\
\hline
\end{tabular}

Berdasarkan tabel 1 sebagian besar peserta penyuluhan diikuti oleh karang taruna sebanyak 38 $\%$. Kegiatan penyuluhan sosialisasi dampak penyalahgunaan narkoba di lingkungan masyarakat tepat sasaran berdasarkan jumlah terbanyak peserta penyuluhan. Prevalensi penyalah guna narkoba pada usia 10-59 tahun menempatkan pemuda pada target sasaran pengedar. ${ }^{[10]}$ Karang taruna merupakan organisasi pemuda di masyarakat, yang dapat membentuk jiwa generasi muda yang baik sehingga menjadi harapan bangsa Indonesia. ${ }^{[6]}$ Antusias karang taruna dalam kegiatan sosialisasi diharapakan dapat menyebar luaskan informasi kepada teman sebaya, sehingga harapan kedepan dapat menurunkan prevalensi kasus penyalahgunaan narkoba di masyarakat.

Tabel 2. Distribusi pre-test dan post-test pengetahuan

\begin{tabular}{lccc}
\hline Pengetahuan & $\begin{array}{c}\text { Pre-tets } \\
\mathrm{n}(\%)\end{array}$ & $\begin{array}{c}\text { Post-test } \\
\mathrm{n}(\%)\end{array}$ & $\begin{array}{l}\text { Total } \\
\mathrm{n}(\%)\end{array}$ \\
\hline Baik & $5(33)$ & $10(67)$ & $15(100)$ \\
Cukup & $11(44)$ & $14(56)$ & $25(100)$ \\
Kurang & $10(83)$ & $2(17)$ & $12(100)$ \\
\hline Total & $26(50)$ & $26(50)$ & $52(100)$ \\
\hline$\rho$ Value 0,000 & & &
\end{tabular}


Pengetahuan peserta sebelum sosialisasi dapat teridentifikasi dari kegiatan pre-test yang sebagian besar $83 \%$ berpengetahuan kurang dibandingkan dengan yang berpengetahuan baik $33 \%$, sedangkan setelah sosialisasi hasil post-test sebagian besar berpengetahuan baik $67 \%$ di bandingkan dengan yang berpengetahuan kurang $17 \%$ terkait jenis narkoba dan dampak penyalahgunaan narkoba.

Pengetahuan kurang dari peserta pada saat pre-test, mengidentifikasi bahwa warga desa kurang paham tentang jenis narkoba dan dampak penyalahgunaan narkoba. Menurut BNN, narkoba merupakan singkatan dari NAR yang artinya adalah narkotika, KO adalah psikotropika, dan BA singkatan dari Bahan Adiktif. ${ }^{[2,4,8]}$

Narkotika dibagi dalam 3 golongan yaitu golongan 1 Tidak boleh digunakan sama sekali contohnya ganja, opium, heroin, kokain, daun coca dan sabu. Golongan 2 digunakan dalam medis dan ketergantungan tinggi contoh morfin dan methadon. Golongan 3 digunakan untuk medis dan penggunaan dengan resep dokter serta ketergantungan rendah. ${ }^{[2,3,4,8]}$ Narkotika jenis baru pada tahun 2017 teridentifikasi adalah blue safir atau snow white yang dapat diubah dalam serbuk ataupun cairan. Liquid rokok elektik atau vape banyak didapatkan mengandung blue safir. ${ }^{[9]}$

Psikotropika merupakan zat atau obat, alamiah ataupun sintetis, berkasiat psikoaktif dan dapat merubah aktifitas mental dan perilaku sesorang. Psikotropika yang berupa obat misalkan diazepam ataupun phenobarbital, jika kita konsumsi tanpa tahu standart pengobatan sangat berbahaya, dan termasuk dalam penyalahgunaan narkoba. ${ }^{[2,3,4,8]}$

Bahan Adiktif adalah bahan atau zat yang bukan golongan narkotika maupun psikotropika yang dapat menimbulkan ketergantungan, misalnya alkohol (minuman keras), kafein (kopi), nikotin (rokok), tiner, bensin, spirtus atau zat yang mudah menguap. Batasan penggunaan bahan adiktif diatur dalam kepres dan Perda. ${ }^{[2,3,4,8]}$

Dampak penyalahgunaan narkoba dalam segi kesehatan antara lain kematian, pernafasan yang cepat lelah, peningkatan kerja jantung memicu perpecahan pembuluh darah, otak dan syaraf bekerja secara over, menurunnya nafsu makan dan kulit keriput. sedangkan secara psikologis yaitu mudah marah, sering menyendiri dan suka berkelahi. ${ }^{[2,3,10]}$

$$
\text { Peningkatan pengetahuan peserta }
$$
penyuluhan berdasarkan analisa statistik didapatkan nilai $\mathrm{p}$ value $=0,000$ dan kurang dari $\alpha$ maka sosialisasi dampak penyalahgunaan narkoba di lingkungan masyarakat sangat diperlukan oleh warga desa secara berkesinambungan dan berkelanjutan. Sehingga meningkatkan pengetahuan dan kesadaran masyarakat akan narkoba dan dampaknya dapat menekan jumlah prevalensi penyalahguna narkoba di desa modong kabupaten sidoarjo.

\section{KESIMPULAN}

Kegiatan penyuluhan pada sosialisasi dampak penyalahgunaan narkoba di lingkungan masyarakat yang diikuti warga desa sebagaian besar mengalami peningkatan pengetahuan.

\section{SARAN}

Sosialisasi dampak penyalahgunaan narkoba di lingkungan masyarakat di desa - desa yang ada di kabupaten Sidoarjo sehingga dapat menekan jumlah kasus Narkoba.

\section{DAFTAR PUSTAKA}


1. KBBI, 2018. Pengertian Narkoba. https://kbbi.kemdikbud.go.id/entri/narkoba Sitasi 20 Mei 2019

2. Badan Narkotika Nasional,. 2014. Laporan Akhir Survei Nasional Perkembangan Penyalahguna Narkoba Tahun Anggaran 2014. https://bnn.go.id/laporan-akhir-survei-nasionalperkembangan-penyalahguna-narkoba-tahunanggaran-2014/ sitasi 25 Januari 2019

3. Eleanora. 2011. Bahaya Penyalahgunaan Narkoba Serta Usaha Pencegahan Dan Penanggulangannya (Suatu Tinjauan Teoritis). Journal Hukum . http://jurnal.unissula.ac.id/index.php/jurnalhukum /article/view/203 sitasi 25 maret 2019

4. Anggreni, D. 2015. Dampak Bagi Pengguna Narkotika, Psikotropika Dan Zat Adiktif (Napza). E-Jurnal Sosiatri-Sosiologi, Vol.III, (No.3), pp.37-51.

5. Sholihah, Qomariatus,. 2015. Efektivitas Program P4GN Terhadap Pencegahan Penyalahgunaan Napza. KEMAS: Jurnal Kesehatan Masyarakat. http://journal.unnes.ac.id/nju/index.php/kemas/iss ue/archive Sitasi 3 Maret 2019

6. Ekasasnada, Dewa I,. 2014. Fenomena Kecanduan Narkotika. Journal Sejarah Dan Budaya. http://journal.um.ac.id/index.php/sejarah-danbudaya/article/view/4755 sitasi 25 Juni 2019

7. Kurniasari D,. dkk. 2013. Peranan Organisasi Karang Taruna dalam mengembangkan kreativitas Generasi Muda di Desa Ngembal Rejo. Unnes
Civic

Education

Journal.

http://journal.unnes.ac.id/sju/index.php/ucej sitasi 10 Juli 2019

8. Asni, Rahma, Sarake,. 2013. Faktor Yang Berhubungan Dengan Penyalahgunaan Narkotika Dan Bahan Adiktif (Narkoba) Pada Remaja Di SMA Kartika Wirabuana Xx-1 Makassar. Journal Media Kesehatan Masyarakat Indonesia. sitasi 10 Juli 2019

9. Amanda ,dkk,. 2017 Penyalahgunaan Narkoba di Kalangan Remaja (adolescent Subtance abause). Prosidingan dan Pengabdian Kepada Masyarakat. http://jurnal.unpad.ac.id/prosiding/article/view/14 $\underline{392}$ sitasi 20 Juni 2019

10.Simangunsong, Jimmy. (2015). Penyalahgunaan Narkoba di Kalangan Remaja (Studi Kasus pada Badan Narkotika Nasional Kota Tanjung pinang). http://jurnal.umrah.ac.id/wpcontent/uploads/gravity forms/1ec61c9cb232a03a96d0947c6478e525e/2015/09 /E-jurnal-jimmy.pdf sitasi 25 Juni 2019 